\title{
北海道積丹半島における火砕岩の特性と岩盤崩壊の要因について \\ Properties of pyroclastic rock and controlling factor of the rock mass failure around the Shakotan Peninsula, Hokkaido, Japan
}

\author{
米田哲朗*)・林 謙二*)・ダカール ゴネス*)・柏谷公希*)・金子勝比古*) \\ Tetsuro YONEDA, Kenji HAYASHI, Ganesh P. DHAKAL, Kouki KASHIWAYA and Katsuhiko KANEKO
}

\begin{abstract}
Steep rock slopes composed of pyroclastic rocks of middle Miocene to Pliocene age are formed around the coastal part of Shakotan peninsula, Hokkaido, Japan. Rock mass failure frequently occurs at these area which can be examplified by the rock failure accident at Toyohama tunnel, Feb. 10, 1996. The pyroclastic rocks comprising the slopes is classified into the soft, inhomogeneous type. They are characterized by presence of smectite filling the interspaces between the particles as well as the pores in the rock. It may be possible that the microscopic occurrence of the smectite can be an important factor which controls the change in physical properties of the rock such as durability and hardness under an aqeous weathering condition. In addition, mineralogical feature of the rock may be a promoting factor of crack propagation causing the rock mass failure at such steep slope area.

Key words : pyroclastic rock, smectite, slake durability, physical weathering
\end{abstract}

\section{和文要旨}

北海道稓丹半島の海岸部では，新第三紀中新世中期〜鮮新世の火砕岩からなる急崖斜面が広く発達している。そこでは，1996年 の豊浜トンネル付近の岩盤崩落事故をはじめとして, 少なから呚の岩船斜面崩壊が発生している。それらの急崖を構成する火砕 岩類は, 工学的な分類上不均啠軟岩に相当する岩盤であり, 構成岩片・粒子の間隙や割れ目を充填する産状のスメクタイトを広く 含有することで特徴づけられる。すなわち，このスメクタイトのミクロな分布特性は，水に富む風化環境のもとで，火砕岩の構成 岩片・粒子の接合性や固結度が関係する物理的性状変化を促進させる重要な要因であることが示される。そして，この火砕岩の特 性は, 急崖斜面における岩盤龟裂の伸長など岩盤崩壊の直接的原因に結びつくものと理解することができる。 キーワード：火砕岩, スメクタイト, スレーキング特性, 物理的風化

\section{1. 緒言}

1996年 2 月に発生し20名もの犠牲者を出した豊浜トン ネル岩盤崩落事故以来, 急崖斜面における岩盤の安定性 評価や保全をめぐる問題に大きな関心が寄せられ，岩盤 崩落のメカニズムや原因解明のための調査・研究また予 知・予測技術の開発研究が広く進められてきている ${ }^{1) \sim 5)}$ それらの調査・研究の中で, 岩盤崩落の基本的要因であ る地形・地質構造, 気候, 地下水また地震などの自然的 因子に加えて, 岩盤の地質 - 岩石性状に対して十分な理 解を持つことの重要性が指摘されている。すなわち，急 崖斜面などにおける水の凍結融解や水一岩石反応などに よる岩石風化は, 岩盤中の龟裂の発生・進展など物理的 性状変化ならびに化学的変質をもたらすものであり，岩 盤強度や耐久性の劣化の要因となり得るものと考えられ る。そのような岩盤の安定性の評価や予測の方法を考え ていく上で，岩石の現在の風化状態さらには地質学的な 履歴を把握し, 岩盤の風化と性状変化についての基本的 関係を理解することが重要である1)。そのためには，岩 石の地質工学的方法による強度・耐久性や透水性, さら に岩石鉱物学的な手法による岩石の組成・組織に関する 性質など，岩盤・岩石特性の多面的な検討に基づいた ケーススタディが必要であると考えられる。

筆者らはここ数年来, 岩盤風化と性状変化のケースス

*) 北海道大学大学院工学研究科現境资源工学専攻

Division of Environment and Resources Engineering. Graduate School of Engineering, Hokkaido University

T060-8628 札昽市北区北13条西8 万目

Kita 13. Nishi 8, Kita-ku, Sapporo, 060-8628 Japan
タディの一つとして豊浜地域を含めた積丹半島付近に分 布する火砕岩をとりあげ，地表およびボーリングコア試 料の観察・実験から得られた火砕岩の産状, 組成・組織 また物理的性状について広域的な比較検討を行っている。 今回, 積丹半島沿岸部の豊浜地域, キナウシ地域また積 丹半島東方の忍路地域に分布する火砕岩の鉱物学的特徽 とスレーキングについて述べ，火砕岩の鉱物学的特性お よびそれと関連して進行する性状変化が岩盤崩壊の素因 の一つとして重要であることを指摘したい。

\section{2. 積丹半島沿岸部における岩盤崩落と火砕岩の地質的 特徵}

北海道積丹半島の海岸線では，おおよそ海食によると 考えられている比高50m〜100mを越す急崖地形が連続 的に発達し, 発生時期が不明なものも含め大規模〜小規 模の多くの岩盤崩落の発生が知られている（図－1）。 たとえば, 1974年以降, 当地域では比較的大規模な岩盤 崩落が神恵内キナウシ地域 (規模 $2,000 \mathrm{~m}^{3}$ ), 豊浜地域 セタカムイ (同 $420 \mathrm{~m}^{3}$ )，豊浜地域ワッカケ岬（同27,000 $\left.\mathrm{m}^{3}\right)$, 忍路 (同 $\left.270 \mathrm{~m}^{3}\right)$ そして豊浜トンネル（同 11,000 $\left.\mathrm{m}^{3}\right)$ で発生している5

それら急崖地域の地質は，主に新第三紀中新世中期〜 鮮新世の海底火山活動によりもたらされた中性および酸 性火砕岩類 (水冷破砕岩, 水中軽石流堆積物およびそれ らの二次堆積物など）からなる ${ }^{6) .71}$ 。そのような火砕岩 類から構成される岩層は半島沿岸部に広く分布しており 


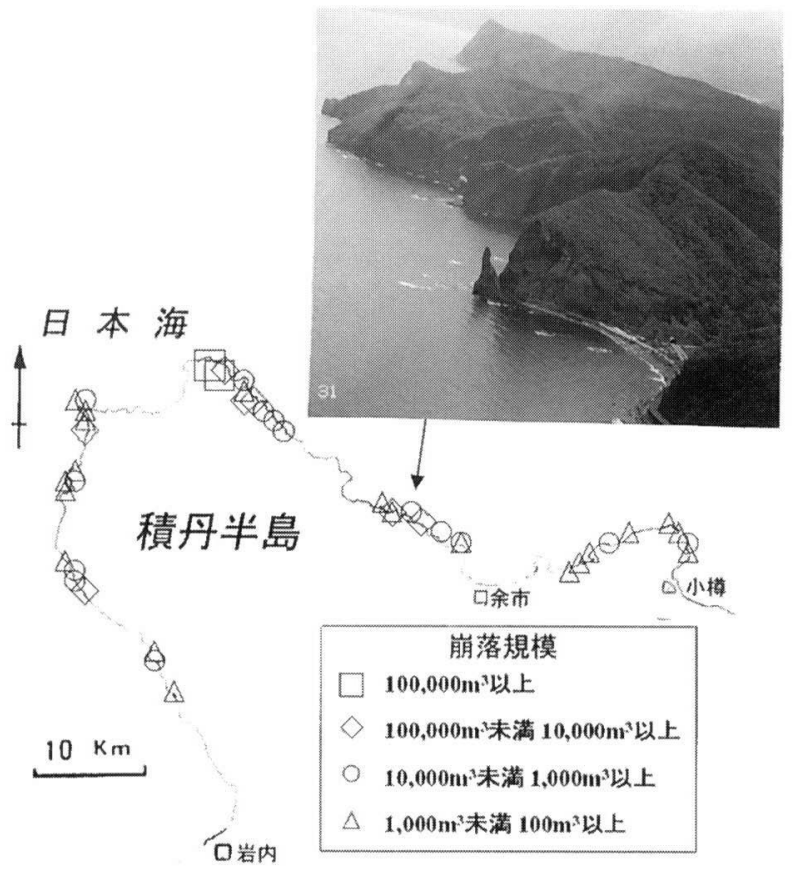

図一１＼cjkstart積丹半島付近における岩盤崩落分布図

(岩盤崩落の機構解明と計測技術に関する研究委員会 $(2000)^{5}$ )の 図に一部手を加えて引用。)

Fig. 1 Distribution of rock mass failures around Shakotan peninsula. Map after the research committee of mechanism clarification and monitoring technique of rock mass failure $(2000)^{5}$ is revised in this study.

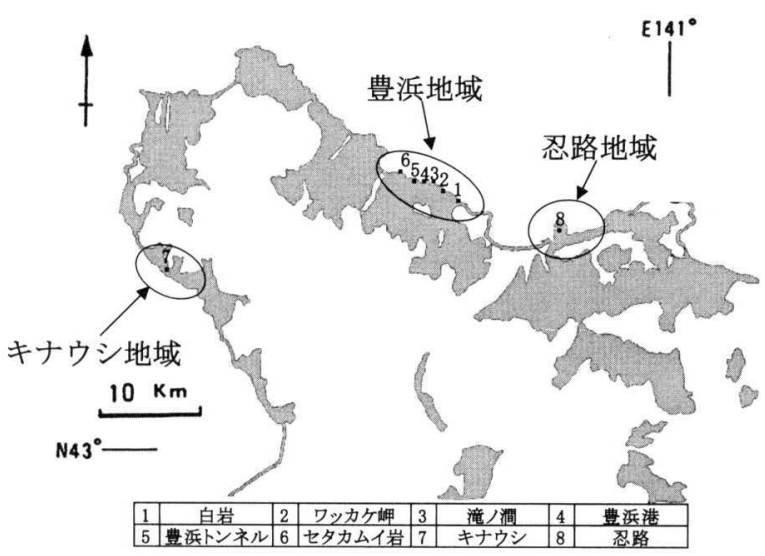

図一２積丹半島付近における火砕岩層の分布図

(塗色部は新第三紀中新世中期—鮮新世の火砕岩層の分布を表す。)

Fig. 2 Distribution of pyroclastic rock formation (colored part) of middle Miocene to Pliocene age around Shakotan peninsula

(図-2), 眓- 1 で示された規模の大きい岩盤崩落はお およそこれらの火砕岩層の分布地域内で発生しているこ とがわかる。

豊浜地域に分布する火砕岩は, 中新世中期〜後期の尾 根内層に区分される安山岩質水冷破砕岩である。上述の 豊浜地域のセタカムイ, ワッカケ䛅および豊浜トンネル における火砕岩は，地質学的にほぼ同時期に形成された 一つの火山体を構成する岩層であり, それらの地点にお ける岩盤崩壊を旧海底火山の側面における山体崩壊であ

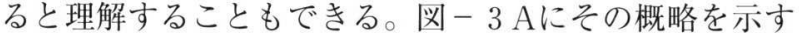
ように豊浜トンネル岩盤崩落現場付近の水冷破砕岩は, 下部よりユニット I 〜 N の四層に区分される1”。崩落岩 体はユニット I ～IIIにまたがる部分であり，その主要部 はユニットII からなる。ユニット I およびIII は成層火砕 岩であり, 斜面上に再堆積した水冷火砕岩であると考え られている。ユニットII は, 下部の角砂質な部分, 中部 の無層理塊状部分, そして上部の成層した比較的細粒部 分の三つのサブユニットに区分される。また， ユニット II については, 豊浜近傍から採取された安山岩の放射年 代值から11.2Maの噴火年代が考えられている ${ }^{8)}$ 。岩盤崩 落現場付近の斜面では，長期間露出した岩盤表面や開口 亀裂部分では風化による褐色化が進んでいるほか, とく に火砕岩の基質部で, 局所的な変質に起因すると考えら れる淡黄色部が随所に認められる。

キナウシ地域の火砕岩は, 新第三紀中新世後期の尾根 内層に区分されるデイサイト質水冷破砕岩である ${ }^{6), 99}$ 。 それら火砕岩の啋と細粒物質からなる基質部の量比は変 化に富み, 自破砕溶岩, 火山角碟岩, 凝灰岩など, 岩相 変化が著しい。また, それら火砕岩は表層に分布する風 化部分をのぞきおおむね新鮮な外観を呈する（図－３Ｂ）。

積丹半島東方の忍路地域では, 新第三紀後期中新世の 俱知安累層に区分されている安山岩質火砕岩が忍路湾お よびその周辺の海岸部に分布している ${ }^{10)}$ 。忍路湾付近で は水冷破砕岩や枕状溶岩など水中火砕流に伴なう種々の タイプの火挽岩から構成され ${ }^{111}$, その周辺の海岸部では 砂質凝灰岩が広く分布している。それら火砕岩の角啋部 分は黒色〜暗灰色で比較的新鮮硬質であるが，基質部分 は淡黄褐色を呈し変質が進んでいる。また，とくに枕状 溶岩の団塊周辺部ないし境界部には黄褐色変質部が網脈 状などをなし特徵的に認められる。

上述の火砕岩とくに水冷破砕岩について, 構成岩片 (砂) の粒径や碟と基質部分との構成割合が大変不規則 で変化に富むことが共通した特徵である。さらに, 火砕 岩の角碟部分はお拉むね黒色〜暗灰色の新鮮硬質で緻密 な火山岩片であるが，基質部分は褐色〜扊黄色〜死色を 呈し比較的脆弱, 時として多孔質であることが特徴的で ある（図－3C）。とくに風化の進んだ表層の火砕岩試 料では基質部の褐色化と脆弱化が著しい。しかし, 肉眼 的に表層風化の影響を受けていないと判断される比較的 深部の火砕岩コア試料中にも粘土細脈が観察されること もある(図一 3 D)。

\section{3. 試料および実験方法}

積丹半島海岸部に分布する火砕岩層から広く試料採取 を行った。とくに上述の 3 地域の地表試料およびボーリ ングコア試料に対し鉱物学的分析とスレーキング試験を 行った。豊浜地域では, 地表露頭 6 力所（白岩, ワッカ ケ岬, 滝ノ澗, 豊浜港, 豊浜トンネル崩落現場, 七夕カ ムイ岩）ならびに新滝ノ澗トンネルと豊浜トンネル崩落 

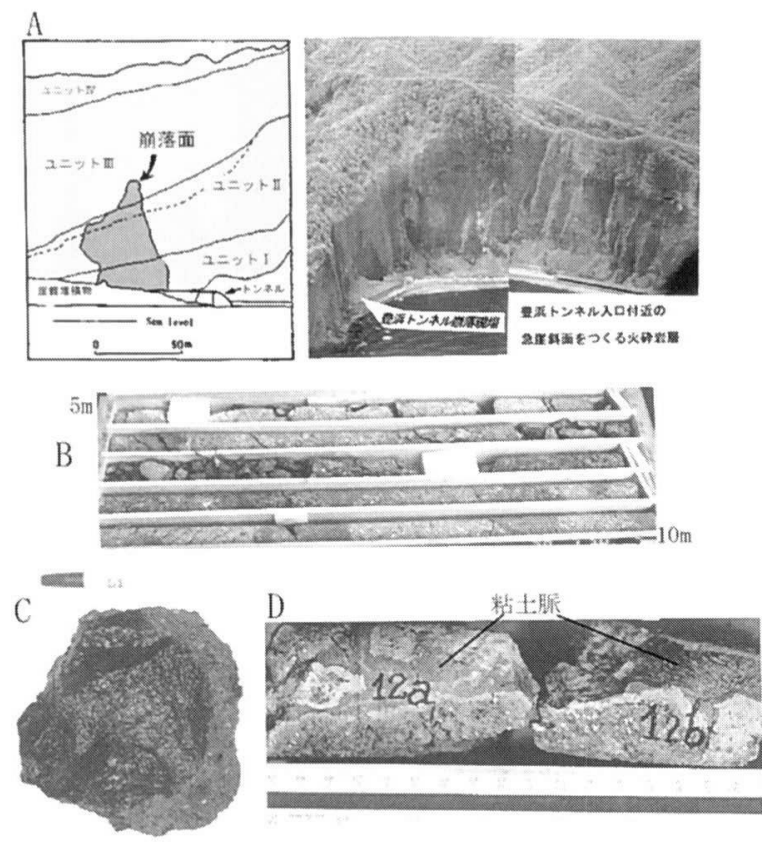

図-3 火砕岩の性状

(A：豊浜トンネル崩落現場付近の火砕岩の産状（左図は豊浜卜ン ネル崩落事故調查委員会 (1996) ${ }^{1)}$ の図を簡略化), B : キナウシ地 域のコア試料, C：安山岩片と細粒多孔質な基質部からなる火砕 岩（豊浜トンネル崩落現場付近）, D：火砕岩中のスメクタイト粘 土脈 (豊浜地域新滝ノ間コア試料)。)

Fig. 3 Occurrence and macroscopic feature of the pyroclastic rock

(A : steep slope of pyroclastic rock near rock fall site at Toyohama tunnel, B: core sample of pyroclastic rock from Kinaushi area, C: a pyroclastic rock sample of andesite rock fragment with fine-grained porous matrix (near rock fall site at Toyohama tunnel), D : clay vein nearly composed of smectite in core sample of pyroclastic rock from Shin-Takinoma in Toyohama area.)

現場付近で行われたボーリングから採取された火砕岩試 料を使用した。キナウシ地域の火砕岩試料は，すべて急 崖斜面で行われたボーリングコアから採取されたもので ある。また, 忍路地域では, いずれも地表露頭から試料 採取を行い, 忍路湾岸斜面の水冷破砕岩と枕状溶岩を, またフゴッぺおよび桃岩付近の砂質凝灰岩を実験試料に 用いた。

採取したすべての火砕岩試料に対し，試料の粉末を蒸 留水中で超音波分散した後, 遠心分離により粒径 $2 \mu \mathrm{m}$ 以下の粘土分を回収し，粘土試料を得た。粘土鉱物の同 定のため, これら粘土の未処理とエチレングリコール飽 和（EG）処理の定方位試料に対しX線粉末回折（XRD） 分析 (日本電子JDX -3500 ，管電圧 $/$ 電流 $40 \mathrm{KV} / 200$ $\mathrm{mA}$ ，スリット系： $0.5^{\circ}-0.2 \mathrm{~mm}-0.5^{\circ}$ ，ステップ角度

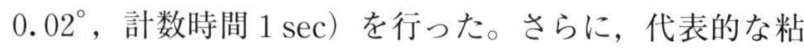
土試料を選び，不定方位試料についてXRDによる粘土 鉱物のd（060）反射ピークの測定を行った。また，い くつかの試料に対し全岩試料のXRD分析を行い，鉱物 組成を調べた。

上記のXRD分析から得られたXRDデータを用い，結 晶子 (スメクタイト) の粒径（干渉散乱領域の大きさ）
評価を試みた。EG処理のスメクタイトの001回折ピーク に対して，粉末X線回折における試料の粒径と関係づけ られる半価幅 (FWHM) を計測するとともに, 計算プ ログラムMudmaster ${ }^{12)}$ を用いて，BWA (Bertaut-Warren -Averbach）法による粒径解析 ${ }^{13)}$ を行った。

また, 試料の研磨薄片を作成し, 偏光顕微鏡（オリン パスBX60およびニコンHQ130-PA160システム）によ り，火砕岩の鉱物組成および組織を調べた。そして，そ れら薄片を用いて電子線プローブ微小部分析装置 (EPMA：日本電子製JXA-8900M）による構成鉣物の 定量化学分析と主要元素の特性X線による化学組成マッ ピングを行った。さらに, 代表的ないくつかの粘土試料 に対し，分析透過型電子顕微鏡（ATEM：日立製作所H -700およびHoriba EMAX-2200）による透過像観察 および化学分析も行った。

火砕岩の風化環境下における耐久性を調べるため, ISRMの指針 ${ }^{14)}$ に基づくスレーキング試験を行った。試 験方法はASTMに従い，採取した試料を砕き，質量測 定した40〜60gの岩片を10個用意した。これを $105^{\circ} \mathrm{C} の$ 恒温槽にて約 4 時間乾燥させた後，スレーキング試験装 置（JACOM製JTR-140A）のドラムに入れ，ドラム回 転軸下 $2 \mathrm{~cm}$ まで蒸留水が入った水槽内でドラムを 10 分 間回転 $(20 \mathrm{rpm})$ させた。その後ドラム内から岩片を取 り出し, $105^{\circ} \mathrm{C}$ の恒温槽で約 4 時間乾燥させ, 乾燥後約 1 時間冷却するのを待ち，質量を測定した。ドラム中での 回転一乾燥一質量測定までを 1 サイクルとし，これを10 サイクル繰り返した。

\section{4. 火砕岩の鉱物学的特徵}

\section{1 変質鉱物の産状}

火砕岩試料に対する光学顕微鏡観察, XRD分析および EPMA分析の結果, 安山岩質火砕岩試料（豊浜および 忍路）では，斜長石，輝石および火山ガラスが砕首粒子 や基質部に広く観察され，またデイサイト質火砕岩（キ ナウシ）ではそれらに加えて石英，角閃石执よび黒雲母 が認められた。それら主要構成鉱物は，鏡下で，おおよ そ新鮮である場合が多いが，キナウシ地域のデイサイト 質火砕岩では有色鉱物のオパサイト化など変質が進み污 濁しているものが多い。上記のほか, 豊浜では磁鉄鉱, マ グへマイトおよびチタン鉄鉱が鏡下で普通に認められる。 変質鉱物については，ほぼすべての火砕岩試料からス メクタイトが認められ，積丹半島沿岸地域の火砕岩には スメクタイトが広範囲に含まれることが判明した。その 一例として, 図- 4 に豊浜地域新滝ノ澗トンネルおよび キナウシ地域のボーリング柱状図（それぞれS $1-3$ お よびAB 3 ）と採取コア試料から認められたスメタタイ トのX線回折パターンを示す。いずれのボーリングコア においても，下部から上部まで広くスメクタイトが産出 することが分かる。なお，図－4には後で述べるスメク タイトの粒径解析結果も併せて示している。 

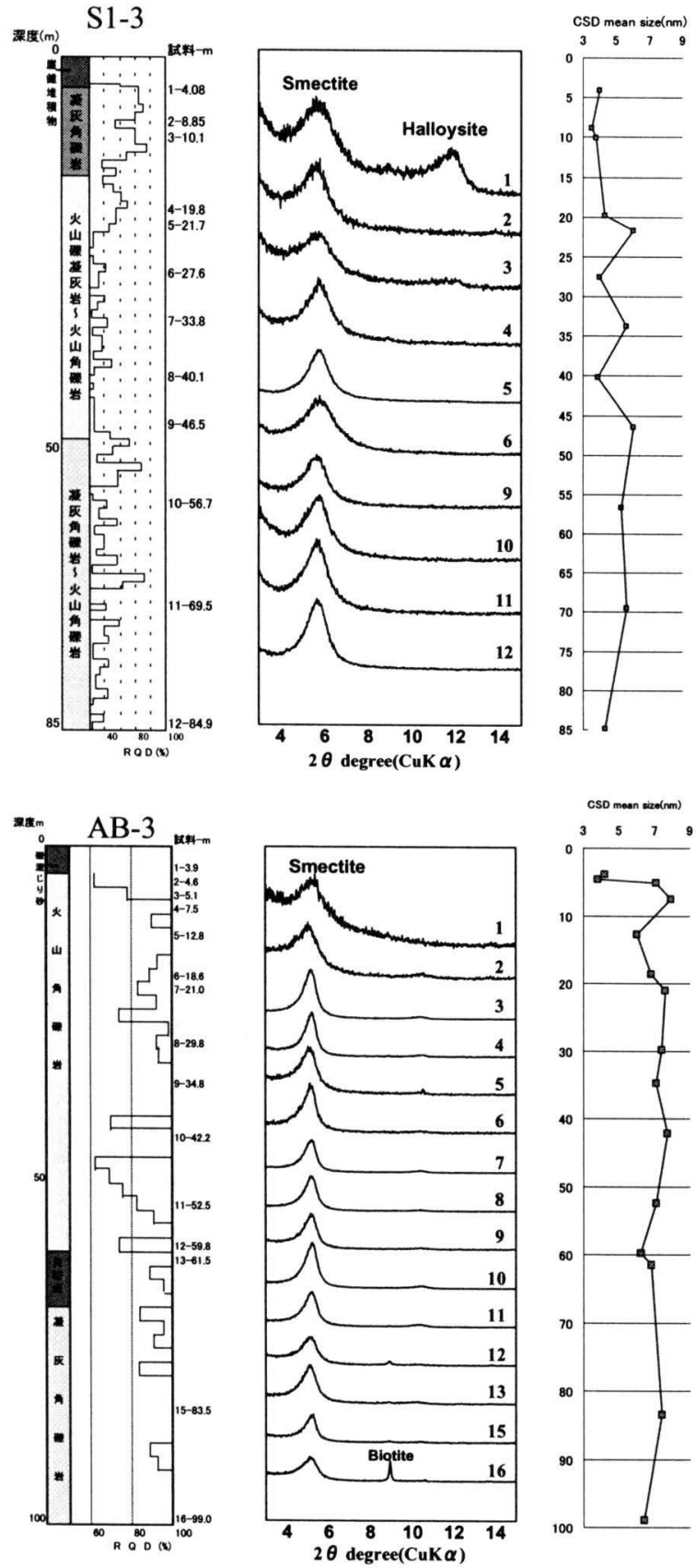

図一４スメクタイトの産出状態の一例

(ボーリングコアに見られるXRDパターンと平均粒径の変化。 $\mathrm{S} 1$ -3 : 豊浜地域新滝八間, AB 3 : キナウシ地域。)

Fig. 4 XRD patterns and variations in mean crystallite size of smectite of pyroclastic rock samples from two drilling holes $(\mathrm{S} 1-3$ and $A B-3)$. S 1-3 : Shin-Takinoma in Toyohama area, AB 3 : Kinaushi area

これら火砕岩中のスメクタイトは, 光学顕微鏡下で淡 黄色〜褐色を呈する微細粒子集合体として，とくにその 基質部中に広く分布する。それらスメクタイトは，火砕 岩の基質部分で粒子の間隙を充填する状態や粒子表面を 被覆し網脈状をなし含有される産状で認められることが 特徵である（図－5A）。このほか，火山岩粒子の石基 中で，真珠状あるいは不規則な微細割れ目を充填したり，
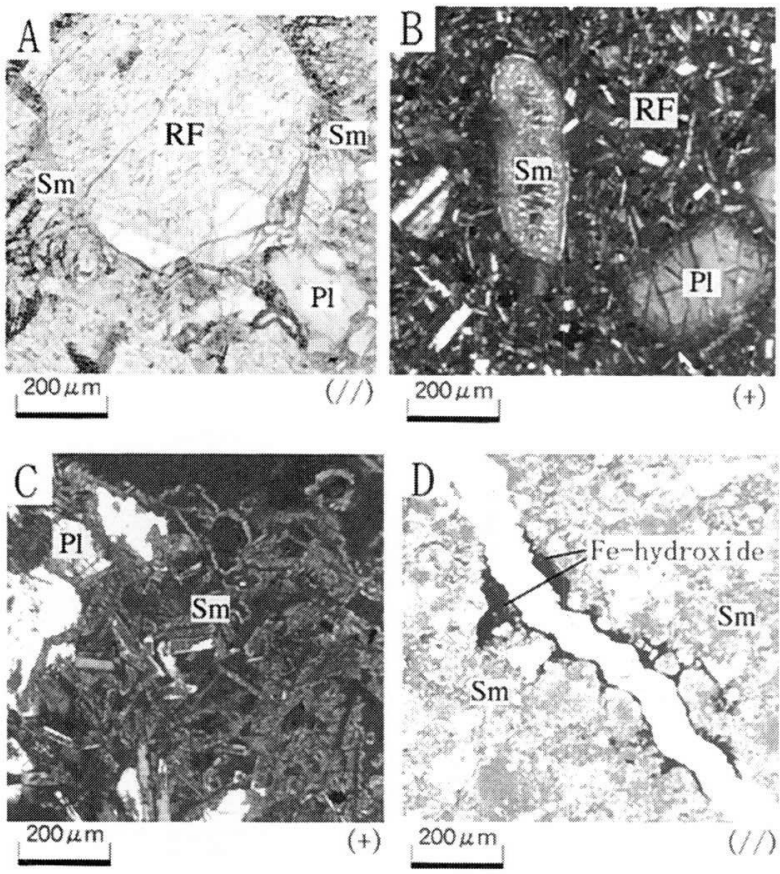

$\mathrm{RF}$ : 岩片 $\mathrm{Pl}$ : 斜長石 $\mathrm{Sm}$ : スメクタイト

図- 5 火砕岩の偏光顕微鏡写真

Fig. 5 Microphotographs of pyroclastic rock samples

丸い空隙を充填あるいは内部壁面をコロフォーム状に被 覆するなどの例も観察される（図－5 B)。さらに，表 層の風化試料中では，スメクタイトが基質部中の斜長石 やガラス質物質を交代する産状を示すものも観察される (図-5C)。

その他の変質鉱物として，一部の試料からクリストバ ライトが認められるほか，表層の風化試料からはハロイ サイトが検出された。さらに，キナウシの火砕岩試料か ら熱水変質による生成物と考えられる自形〜半自形の黄 鉄鉱が特徵的に認められる。これらのほか, 黄褐色化し風 化の影響を受けたと考えられる試料中に，鏡下で不定形 の集合体をなす水酸化鉄鉱物が広く観察される(図 - $5 \mathrm{D})$ 。

上述のように，火砕岩試料中のスメクタイトは，多く の場合亀裂や空隙を充填したり，砕屑粒子を被覆する状 態で認められる。その一例として，スメクタイトのミク 口な産状を示す二次電子線像拈よび特性X線のカラー マップを示した（図-6)。スメクタイトは，鉄・マグ ネシウムに富むことが特徵であり，長柱状〜針状の斜長 石（Ca，Alに富む）を含む砕屑粒子の表面を被覆あるい は間隙を充填し, 全体としてネットワーク状に分布して いることがよくわかる。この試料は，地表風化の影響を 受け生成したと考えられる八ロイサイトが共存しており， スメクタイトの外側（空隙側）に帯状に重なるハロイサ

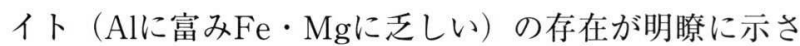
れている。

\section{2 スメクタイトの鉱物学的特性}

XRD分析から得られたスメクタイトの001ピーク（図 - 4 に示されている) に対して行った粒径解析と半価幅 

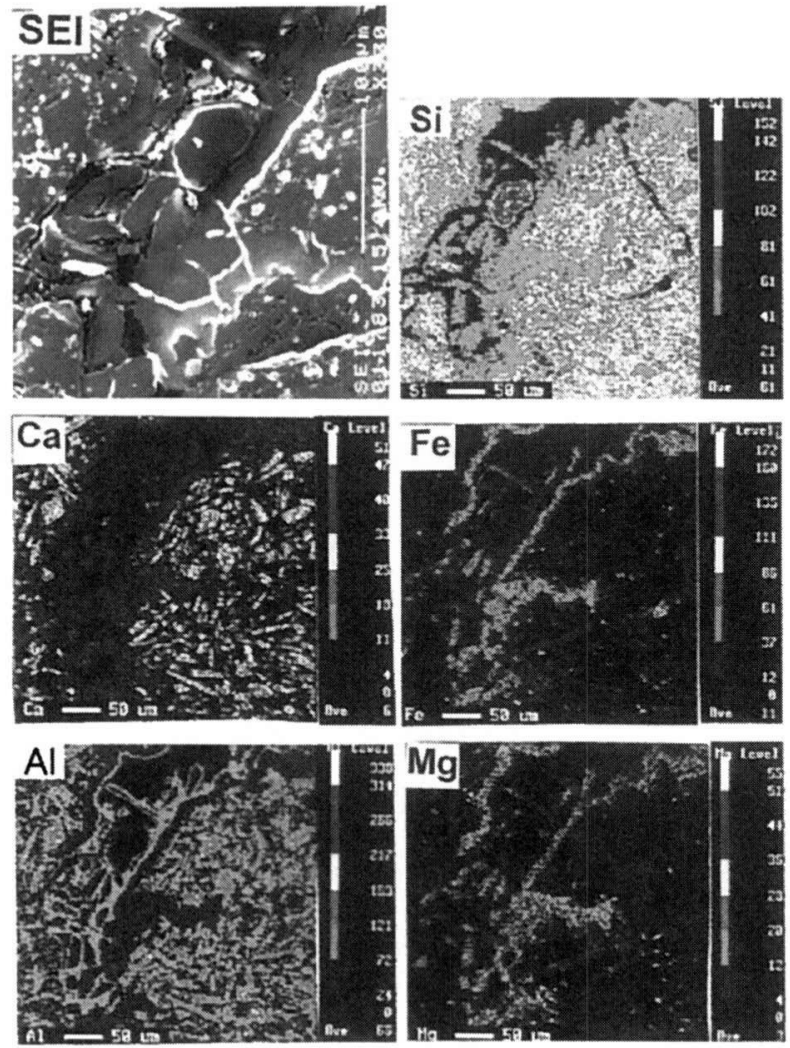

図ー6 火砕岩のEPMAによる化学組成マッピング

(スメクタイトとハロイサイトが共存する表層風化試料(豊浜地域) 明るさの程度が強いほど，㧍拈よそ含有量が高いことを示す。）

Fig. 6 Secondary electron image (SEI) and chemical images ( $\mathrm{Si}, \mathrm{Ca}, \mathrm{Fe}, \mathrm{Al}$ and $\mathrm{Mg}$ ) of surficial weathered rock sample showing coexistence of smectite and halloysite. Brighter part in chemical image shows higher chemical concentration in comparison with darker one

の計測結果を比較した（図-7)。豊浜およびキナウシ 地域のスメクタイトの平均粒径は $3 \sim 8 \mathrm{~nm}$ の範囲にあ り, 半価幅は $0.5 \sim 1.4$ の範囲の值を示している。スメク タイトの平均粒径と半価幅は負の相関性を有しており, 粒径の減少と回折ピークのブロードニングの関係として 知られていることと調和的である。これら粒径パラメー ターはそれぞれの地域で変動幅があるものの, 豊浜地域 ではキナウシ地域のものに比べ小さい精径（大きい半価 幅）を示すものが多く，スメクタイト粒径に地域差があ ることが示される。さらに，キナウシの例に見られるよ うに，地表部の褐色化した火砕岩中のスメクタイトの粒 径が明らかな減少傾向を示して抢り (図-4参照), 表 層風化の影響によりスメクタイトの粒径変化が生じる場 合があることを示唆している。

各地域の代表的火砕岩試料について, EPMAによるス メクタイトの定量化学分析を行った。その結果から 2 八 面体型スメクタイトの主成分である $\mathrm{SiO}_{2}-\mathrm{Al}_{2} \mathrm{O}_{3}-\mathrm{Fe}_{2} \mathrm{O}_{3}$ のモル比を図-8の三角図にプロットし,2八面体型スメ クタイト（モンモリロナイト，バイデライト，ノントロ ナイト）の理想式と比較した。眓ー8に示されるように，

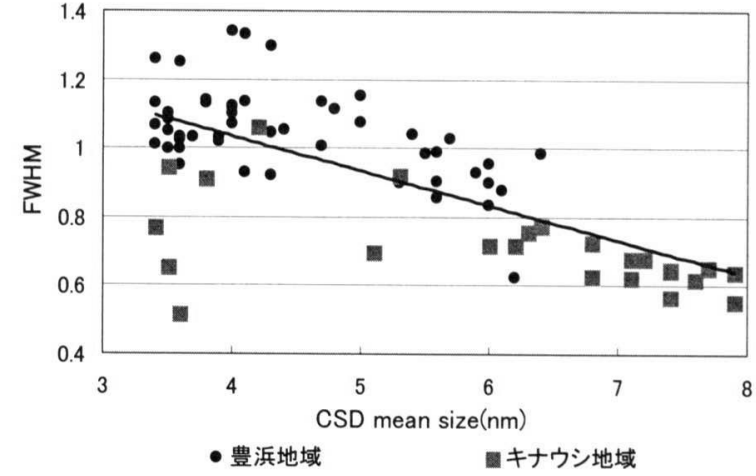

図ー7 XRDによるスメクタイトの平均粒径とピーク半価幅

Fig. 7 Mean crystallite size (mean size of coherent scattered domain) vs. full width at half maximum of XRD peak of smectite

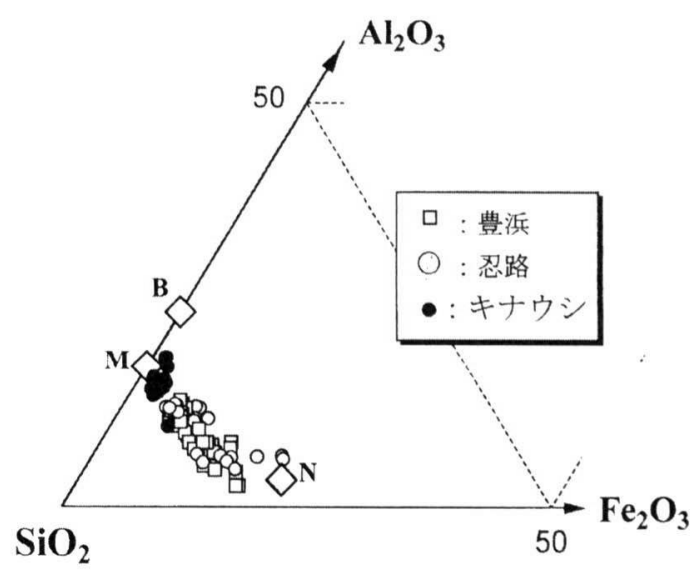

\begin{tabular}{|lc|}
\hline $\mathrm{N}:$ Nontronite & $\left\{\mathrm{EC}_{\}_{0.33} \mathrm{Fe}_{2}{ }^{3+}\left(\mathrm{Si}_{3.67} \mathrm{Al}_{0.33}\right) \mathrm{O}_{10}(\mathrm{OH})_{2}}\right.$ \\
$\mathrm{M}:$ Montmorillonite & $\{\mathrm{EC}\}_{0.33}\left(\mathrm{Al}_{1.67} \mathrm{Mg}_{0.33}\right) \mathrm{Si}_{4} \mathrm{O}_{10}(\mathrm{OH})_{2}$ \\
$\mathrm{~B}:$ Beidellite & $\left\{\mathrm{EC}_{0.33} \mathrm{Al}_{2}\left(\mathrm{Si}_{3.67} \mathrm{Al}_{0.33}\right) \mathrm{O}_{10}(\mathrm{OH})_{2}\right.$ \\
\hline
\end{tabular}

図ー8 スメクタイトの化学組成変化

Fig. 8 Ternary plots of $\mathrm{SiO}_{2}-\mathrm{Al}_{2} \mathrm{O}_{3}-\mathrm{Fe}_{2} \mathrm{O}_{3}$ mole ratios of smectite

積丹半島に分布する火砕岩中のスメクタイトは, $\mathrm{Al}_{2} \mathrm{O}_{3}$ と $\mathrm{Fe}_{2} \mathrm{O}_{3}$ の間で広い組成変化を示している。それらの多 くはモンモリロナイトとノントロナイトの中間的な $\mathrm{Al}$ 一 Fe組成を持つスメクタイトであると理解される。また, 豊浜打よび忍路地域のスメクタイトはややFeに富むも のが多く，一方キナウシ地域のそれはFeにそしくAlに 富むものが多いという傾向があり，地域差が認められる。

以上述べた積丹半島沿岸部に分布する火砕岩中での久 メクタイトの二次的生成の要因すなわち火砕岩変質の原 因については, 現在の陸上の表層風化や火砕岩生成以降 の海底風化さらに熱水作用など複合的な地質学的プロセ スが関与したものと考えられている ${ }^{16}$ 。

\section{5. 火砕岩のスレーキング特性}

述べたように，火砕岩中のスメクタイトのミクロな産 出状態として, 基質部分で粒子の間隙を充填する状態や 
表ー1 スレーキング試験試料一覧

Table 1 Brief description of rock samples used for slake durability test.

\begin{tabular}{|c|c|c|c|}
\hline 岩質 & 試料名 & 特徽 & 産地 \\
\hline \multirow[t]{5}{*}{ 細粒火碎岩 } & STF 1 & 黄褐色の細粒砂贒凝灰岩 & 挑岩 (忍路地域) \\
\hline & STF2 & 灰蝎色の細粒砂質凝灰岩 & セタカム岩 (豐浜地城) \\
\hline & STF3 & 黄蝎色の細粒砂質凝灰岩 & フコッッペ(忍路地域) \\
\hline & STF 4 & 灰蝎色の稩粒砂質疑灰岩 & フゴッペ(忍路地域) \\
\hline & STF5 & 黄蝎色の細粒〜粗粒砂貿凝灰岩 & フゴッペ(忍路地域) \\
\hline 粗䊉火砕岩 & $\mathrm{HCl}$ & 全体的に緑〜灰色の水冷破碎岩 & 豊浜 (豊浜地域) \\
\hline 凝灰質秒岩 & (比較訊料) & 黄蝎色の風化疑灰質砂岩 & 島根県来待 \\
\hline
\end{tabular}

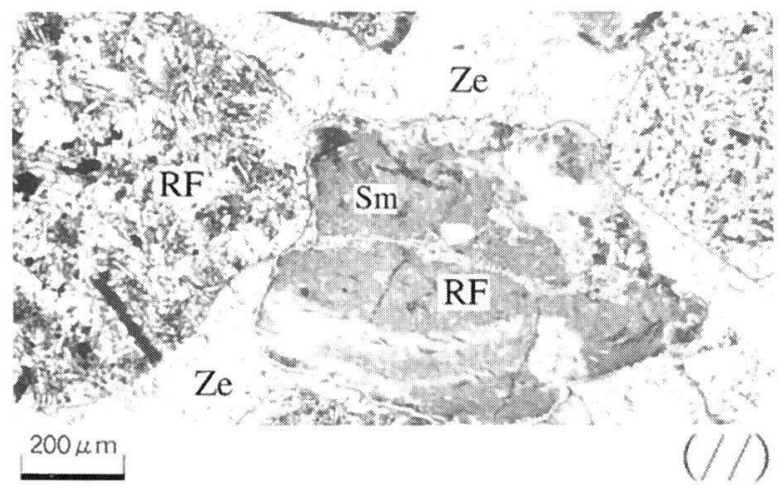

$\mathrm{RF}$ : 背片 Sm：スメク多イト Ze：韲石

図一 9 比較試料（来待産凝灰岩質砂岩）の偏光顕微鏡写真

Fig. 9 Microphotograph of tuffaceous sandstone (comparative rock sample) from Kimachi area, Shimane Prefecture, Japan

粒子表面を被覆し網脈状をなし含有される状態が特徵的 である。膨張性粘土鉱物であるスメクタイトのこのよう な分布特性は，岩石の構成岩片・粒子の接合性や固結度 に関係し，水に富む風化環境下での岩盤耐久性の支配要 因となることが考えられる。このため，主に，豊浜およ び忍路地域から採取したスメクタイトを含む細粒火砕岩 (砂質凝灰岩) のスレーキング試験を行い, 乾燥・湿潤 状態の繰り返しと回転による磨耗に対する岩石の抵抗性 を調べた。用いた火砕岩試料の一覧を表ー 1 に示す。

比較試料として島根県来待産の風化凝死質砂岩につい て同様のスレーキング試験を行った。比較試料は，顕微 鏡観察抢よびXRD分析結果より，積丹半島の火砕岩試 料とほぼ同様の大きさの砕屑粒子からなり（図－9）, 少量（同程度）のスメクタイトを含有すると見なしうる 岩石である ${ }^{17)}$ 。しか， スメクタイトは砕屑岩片中に含 まれることが多く，砕屑粒子間は主に沸石の充填により 特徵づけられること，さらに，スメクタイトは 3 八面体 型の鉄サポナイトであることが積丹産火砕岩と比べて大 きく異なっている。また，比較試料の細孔分布について， スレーキング実験に用いた積丹産火砕岩の一つ（ST 1) と比較すると, 平均細孔半径（それぞれ515.3nmおよび 12. $20 \mathrm{~nm} ）$ と相対細孔体積がやや異なるものの累計細孔 体積 $\left(127.2 \mathrm{~mm}^{3} / \mathrm{g}\right.$ 掞よび $\left.159.6 \mathrm{~mm}^{3} / \mathrm{g}\right)$ はほぼ同様の 值を示している ${ }^{17)}$ 。

スレーキング試験における試料の形状変化と質量変化
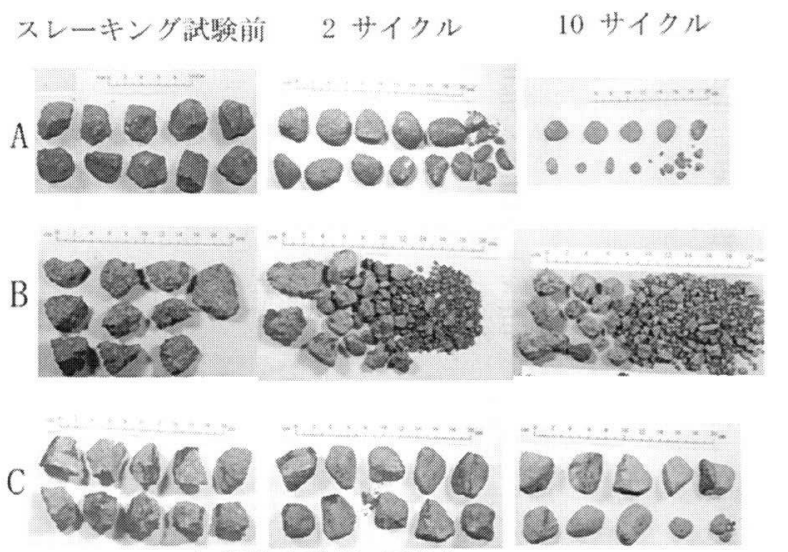

\author{
A: 細䊀火碎砍 (STF1) \\ $\mathrm{B}:$ 粗粒火磁岩 ( $\mathrm{HCl}$ )

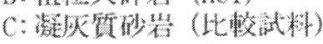

図ー10 スレーキング試験における試料片の形状変化

Fig. 10 Change in shape of the rock samples during slake durability test

(A : fine-grained pyroclastic rock, B : coarse-grained pyroclastic rock, $\mathrm{C}$ : tuffaceous sandstone (comparative rock sample).)

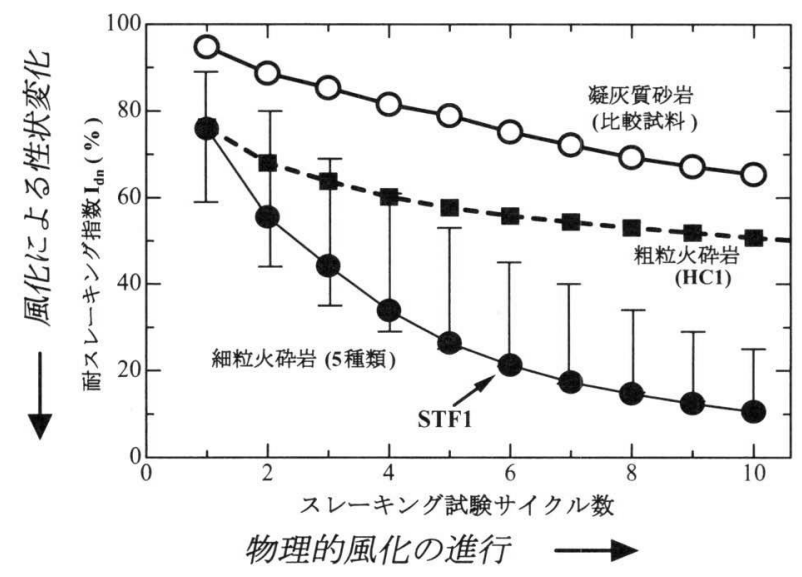

図ー11 火砕岩試料のスレーキング特性

Fig. 11 Slake durability (slaking index \% vs. number of cycle) of pyroclastic rock samples. Vertical and horizontal axes can be taken as rock aspect change and process intensity of physical weathering (mainly wetting and drying), respectively

$(\bigcirc$ : tuffaceous sandstone (comparative rock sample), : coarse -grained pyroclastic rock, : fine-grained pyroclastic rock (sample STF 1).)

の特性曲線をそれぞれ図ー10と図ー11に示した。試料の スレーキングし難さを, 試験前の乾燥重量に対する 2 サ イクル後の乾燥重量の割合 $\left(I_{\mathrm{d} 2}\right)$ であらわすと, 積丹産 細粒火砕岩試料は $40 \%$ ～80\%の範囲にあり，比較試料の それ $(89 \%)$ に比べ低い耐スレーキング指数を示す。ま た，10サイクルまでのスレーキング指数をプロットした 特性曲線についてみると, 積丹産火砕岩試料は明瞭によ り高い減量割合で推移しており，比較試料に比べ明らか にスレーキングしやすいと評価される。なお，図－10の 試料の変状写真で見られるように, やや粗粒火砕岩試料 
（HC 1）は, 細粒分から $2 \mathrm{~mm}$ を超える粗粒分まで幅広 い粒径の火山砕屑物粒子からなる不均質岩である。この ため, 径 $2 \mathrm{~mm}$ を超える砕居物粒子の構成割合の影響を 考慮する必要があるものの, 耐スレーキング指数 $\mathrm{d}_{\mathrm{d} 2}$ は比 較試料と比べて低い值 $(64 \%)$ を示しており, 積丹産細粒 火砕岩試料と同様にスレーキングしやすいと評価できる。

このような積丹産火砕岩試料と比較試料のスレーキン グ特性の違いを，変質鉱物として含まれるスメクタイト のミクロな分布特性の相違に結びつけることができる。 すなわち, 火砕岩では, 粒子間隙などの細孔を通路とし て浸透する水によるスメクタイトの膨潤などが主要因で あると考えられる。一方, 比較試料の来待砂岩では火山 岩片中に含まれるスメクタイトが岩片粒子の結合性の低 下に大きく影響しなかったと推察できる。さらに，火砕 岩と比較試料のスメクタイトが異なった鉱物種であるこ と(火砕岩中のスメクタイトはFeに富むモンモリロナ イトーノントロナイトであり, 来待砂岩のそれはFeサ ポナイトである ${ }^{12}$ ）も影響している可能性が考えられる。 いずれにせよ, 積丹半島沿岸部に分布する火砕岩中のス メクタイトの存在は, 風化の進行に伴う火䂶岩の性状変 化を支配する要因となり，急崖斜面岩盤の耐久性や安定 性に影響するものと考えられる。

\section{5. 火砕岩特性と岩盤斜面崩壊の要因}

積丹半島地域の急崖岩盤斜面に対する防災対策のため の実態調查さらに岩盤崩落メカニズムや原因解明のため の調査研究が数多く行われている。そして, 積丹半島沿 岸部を含む広域的な岩盤斜面崩壊の実態調查の結果, 岩 盤斜面の崩落様式は 4 つのタイプに分類されること（図 -12), また, いずれのタイプにおいても崩落岩体を分 離する龟裂進行と分離面付近に扔ける風化状態がそれら 岩盤斜面の安定性評価にとって重要であること ${ }^{5)}$ ，など が明らかにされている。とくに豊浜トンネルの岩盤崩落 に関して, 岩体の力学的釣り合いを変化させ崩落に導い た直接的原因として, 崩壊面（背面）に扔ける亀裂の発 生と低速伸長が重要であることが指摘され ${ }^{11,2), 41,187,19), 201: と,}$ 岩盤中の龟裂進展が火砕岩からなる急崖斜面崩壊に対す る支配要因となっていることが示されている。

そのような岩盤の亀裂を伸長させる要因として, 風化 作用とくに低温下の物理的風化および乾湿風化を挙げる ことができる ${ }^{211}$ 。低温下の物理的風化は，(1)凍結融解プ ロセスにおける水分移動とアイスレンズ成長，(2)低温の 水による岩石の水和破砕（吸着水分子の斥力に起因する 破砕), また(3)凍結時の間隙水圧および亀裂内水圧の発 生などによる岩石破砕の進行である。それらはいずれも 引張応力の作用下での急崖岩盤の亀裂伸長要因であり, 寒冷地の風化環境下の岩船に特徴的な要因であると考え ることができる。さらに, 岩石の乾湿繰り返しによる風 化は, 上記(2)の破砕進展メカニズムが関係する岩石の膨 張・収縮による破砕である。本研究で得られた火砕岩試
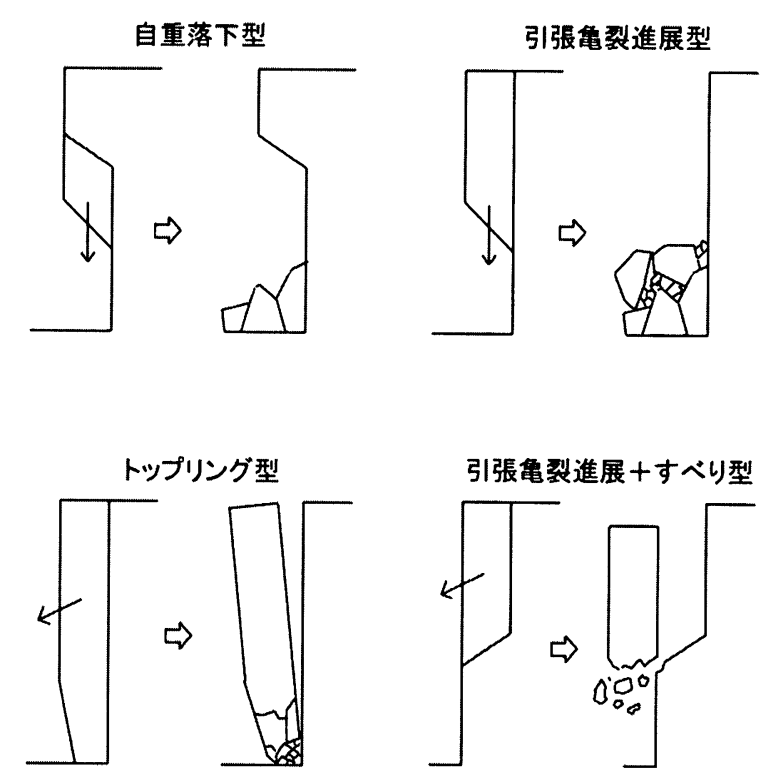

図ー12 積丹半島付近における岩盤の崩落様式のタイプ (北海道古平町国道229号線岩盤崩落調查委員会 $(1997)^{2)}$ の図を加 筆して使用。)

Fig. 12 Types of rock mass failure in Shakotan peninsula. Diagram is quoted from the investigative committee of rock mass falls along Route229in Furubira, Hokkaido $(1997)^{2)}$, and revised in this study

料のスレーキング特性は, 乾湿風化プロセスにおける火 砕岩中の亀裂進展のし易さを示すものと考えることがで き, 同様の環境下にある急崖斜面の岩盤亀裂伸長の要因 となるものであろう。それらのほか, 岩石の応力腐食や 地震による動的応力の影響を考えることができよう。応 力腐食割れは, 引張応力の作用下で水分が存在する場合 には応力の值が強度以下であっても亀裂が低速に伸長す る現象であり，水に富む表層風化環境における岩盤中の 亀裂伸長を促進させるものとして急崖斜面における岩盤 亀裂伸長の要因に数えることができる。また，地震（振 動）による動的応力は亀裂伸長の加速要因として働くこ とが考えられ, 地震（振動）の影響を要因の一つに挙げ ることができょう。

述べたように, 急崖岩盤の亀裂伸長に起因する不安定 化と崩落にとって, 岩石の物理的風化は重要な影響を及 ぼすことが理解される。とくに, 積丹半島地域の急崖斜 面を構成する火砕岩の特性，すなわち膨張性粘土鉱物で あるスメクタイトのミクロな分布特性などは，風化プロ セスにおける龟裂進展を含む物理的性状変化を助長する 役割を果たすものと見ることができる。前章のスレーキ ング特性の比較結果は, このことを示唆するとともに, 火哗岩の物理的性状変化の解析にとって鉱物学的特性の 理解が不可欠であることを示している。

\section{6. 結語}

北海道積丹半島の海岸部では, 新第三紀中新世中期〜 鮮新世の灭砕岩からなる急崖斜面が広く発達している。 
そこでは，1996年の豊浜トンネル付近の岩盤崩落事故を はじめとして，少なからぬ数の岩盤斜面崩壊が発生して いる。それらの急崖を構成する火砕岩類は，工学的な分 類上不均質軟岩に相当する岩盤であり，構成岩片・粒子 の間隙や割れ目を充填する産状のスメクタイトを広く含 有することで特徵づけられる。すなわち，膨張性粘土鉱 物であるこのスメクタイトのミクロな分布特性は，水に 富む風化環境のもとで，火砕岩の構成岩片・粒子の接合 性や固結度が関係する物理的性状変化を促進させる重要 な自然的要因であることが示される。そして，この火砕 岩の特性は，急崖斜面における岩盤亀裂の発生・伸長や 岩盤支持力の低下など岩盤崩壊の直接的原因に結びつく ものと理解することができる。さらに，それら火砕岩の 特性は，地震などによる振動や海食による機械的破壊に 対する岩盤の耐久性や抵抗性の劣化・減少の促進要因と なることも考えられる。このように，本地域における火 砕岩の特性は岩盤斜面崩壊の重要な自然的要因の一つで あるといえる。本地域における火砕岩岩盤斜面の安定 性・耐久性を評価し, 防災・保全のための具体的な指針 を得るためには，風化の進行に伴う岩石性状変化につい て, 理論, 室内実験さらにフィールド調查・計測による 基礎的・総合的な検討の必要性が指摘される。

\section{謝辞}

本論文にて検討結果を述べた火砕岩ボーリングコア試 料は, 筆者の一人（米田）が参加した地盤工学会北海道 支部「岩盤崩落の機構解明と計測技術」に関する研究委 員会に対して北海道開発局が提供したものである。ここ に記して，同委員会および北海道開発局の関係各位に深 謝の意を表する。

\section{参考文献}

1）豊浜トンネル崩落事故調査委員会（1996）：豊浜トンネル崩落 事故調查報告書, $218 \mathrm{p}$.

2 ) 北海道古平町国道229号線岩盤崩落調査委員会 (1997)：北海 道古平町国道229号線岩盤崩落調查委員会報告書地般工学会, $183 \mathrm{p}$.

3 ) Ishijima, Y. and Fuji, Y. (1997) : A study on the mechanism of slope failure at Toyohama tunnel, Feb. 10, 1996, Int. J.
Rock Mech. \& Min. Sci. Vol. 34, Nos. 3-4, Paper No. 087.

4 ）中島餀・米田哲朗 (1998)：豊浜トンネル坑口岩盤の崩壊機構 に関する一考察, 資源・素材 '98(A) 岩盤工学, pp. 21-24.

5 ) 岩盤崩落の機構解明と計測技術に関する研究委員会 (2000) : 岩盤崩壊の発生機構と計測技術, 地盤工学会北海道支部, 226p.

6) Yamagishi, H. (1981) : Geology of the Shakotan peninsula Hokkaido, Japan, Rept. Geol. Survey Hokkaido, 52, pp. 1- 29.

7 ）渡辺寧 $(2000)$ ：札幌一岩内地域マグマー鉱化熱水系分布図, 特殊地質図 38 , 地質調查所

8 ）宇井忠英・広瀬亘（1997）：豊浜トンネル岩盤崩落事故現場の 水冷火砕岩の岩石記載学的特徵, 北海道地区自然災害科学資 料センター報告, 12 , pp. 21 - 30 .

9 ）通産省資源エネルギー庁（1985）昭和59年度広域調查報告書 積丹地域, 156p.

10）長谷川潔-小山内熙（1977）：国富-定山溪地域の地質と鉱床, 北海道地下資源調査所調查研究報告, $5,37 \mathrm{p}$.

11）山岸宏光（1974）: 北海道地下資源調查所報告, 12 , pp. 63-68.

12) Eberl, D. D., Drits, V. A., Srodon, J., and Muesch, R. (1996) : Mudmaster-A program forcalculating crystallite size distributions and strain from the shapes of X-ray diffraction peaks, USGS, Open-file report, $96-171,44 \mathrm{p}$.

13) Drits, V. A., Eberl, D. D., and Srodon, J. (1998) : X-ray measurement of mean thickness, thickness distribution and strain for illite and illite-smectite crystallites by the BertautWarren-Averbch technique, Clays and Clay Minerals, Vol.46, No. 1 , pp. $38-50$.

14) ISRM (1981) : Rock Characterization testing and Monitoring -ISRM Suggested Methods, Pergamon Press, Oxford, 211p.

15) ASTM (1990): Standard test method for slake durability of shales and similar weak rocks (D4644), Annual book of ASTM Standards Vol. 4. 08, pp. 863-865.

16）米田哲朗・大河原正文 ·渡辺隆（1999）：北海道積丹半島豊浜 トンネル付近の水冷火砕岩に産するスメクタイト, 粘土科学, Vol. 39, No. 2, pp. 53-64.

17) Dhakal, G., Yoneda, T., Kato, M., and Kaneko K. (2002) : Slake durability and mineralogical property of some argillaceous pyroclastic and sedimentary rocks, Engineering Geology, Elsevier, Vol. 65, No. 1, pp. $31-45$.

18）菊池宏吉・水戸義忠（1998）：国道229号線豊浜トンネル上部 斜面の岩盤崩落メカニズムに関する地質工学的考察，応用地 質, Vol. 39, No. 5, pp. 456-470.

19）石島洋二（2001）: 岩船崩壊現象の概要と崩壊のメカニズム, 資源・素材 2001 (札幌)，発表講演資料 岩盤工学, pp. 25-28.

20）三田地利之 (2001)：岩盤崩壊に関わる各種要因の役割, 資源 · 素材 2001 (札棍)，発表講演資料 岩盤工学, pp. $33-36$.

21) Bland, W. and Rolls D. (1998) : Weathering, Arnold and Oxford Univ. Press, $271 \mathrm{p}$

（原稿受付2001年11月26日，原稿受理2002年 4 月27日） 